\title{
An Analytical Interpretation of Cultural Resources in Terms of Digital Archiving
}

\author{
디지털 아카이빙으로서의 문화자원에 대한 해석
}

Jun Min Chung*

\begin{abstract}
This paper starts with the question, what are culture and cultural resources? The meanings of cultural resources are mentioned historically and archaeologically. The culture dynamic is introduced and the cultural resources are interpreted as processes and practices along with which culture is produced and reproduced through the action of individual. Digital archiving concluds that the cultural resources are only meaningful when they are archived with their contexts and processes. Finally paper induces that cultural archives could be valuable, when they are preserved (synthetic), recognized (contextual) and enjoyed (exhibited, experienced or practically used).

\section{초 록}

문화와 문화자원에 대한 물음을 전제로 문화자원에 대한 고고학적, 역사적 해석을 시도하였다. 인간의 개별적 행위를 통한 생산과 재생산의 개념으로 문화를 인식하였으며 그 과정과 실천으로 문화역동성 (cultural dynamic)을 표출하였다. 이 논문은 문화자원을 디지털 아카이빙하기 위해서는 문화자원과 함께 그 자원의 생산과정과 의미맥락이 동시에 표현되어야 함을 주장하고 있다. 궁극에 문화자원에 대한 추론과정에서 문화자원은 자원과 관련한 모든 관계자원이 동시에 보존되고 이것의 의미맥락이 살아 있어야 하며 전시, 체험을 비롯한 실제적 활용이 전제되어야 함을 밝히고 있다.
\end{abstract}

Keywords: cultural resources, culture dynamic, contextual, synthetic, digital archiving 문화자원, 문화역동성, 의미맥락, 총체적 구성, 디지털아카이빙

* Professor, Department of Library and Information Science, Chonnam National University (wizard@chonnam.ac.kr)

- Received : 27 May $2010 \quad$ - Revised : 4 June $2010 \quad$ - Accepted : 15 June 2010

- Journal of the Korean Society for Information Management, 27(2): 217-224, 2010.

[DOI:10.3743/KOSIM.2010.27.2.217] 


\section{Introduction}

Culture is often considered as being historically built in traditional frameworks (Schein 2004; Staber 2006). Some argue that a culture is a set of external constraints shaping individuals' feelings (Hofstede 2003) and behavior or a set of values or meanings that inform organizational members' behavior (Boyacigiller et al. 1996; Martin 2002). Taken together, a culture is a process of self expression by people who are familiar with same language, called culture dynamic (Mascarenhas, A.O. and de Vasconcelos, F.C. 2009), in which it is assumed to be a dynamic set of concepts and understandings resulting from human action and interaction.

Now that leaves room for doubts about what we archive culture or cultural resources? Why do we try to save culture? Is it meaningful culture to be archived? If yes, who is responsible for those archiving and preservation? Until now, preservation of cultural and intellectual works largely meant saving physical objects, and responsibility for doing so was left mostly to institutions like museums and our great public, academic, and research libraries (Zimmerman 20062007). Finally, is it possible to archive cultural resources or culture itself digitally? This paper is going to show why we archive culture and how we can preserve culture digitally through understanding cultural resources.

\section{Characteristics of Cultural Resources}

Cultural resources are produced and reproduced from interactions among communities, and members of communities. Cultural resources, therefore, provide us with information about our past. Then what does that implies that the cultural resources are by-products of people's action and/or reaction. People create records of lives by writing, singing, performing or leaving evidences to show their time. Any media or information resources could be cultural resources.

Generally [natural] resources help to produce goods so they have economic value. Resources have three main characteristics: utility, quantity (often in terms of availability), and consumption (Wikipedia 2010: 'resources'). Also, cultural resources, until now had a tendency to equate itself with cultural heritage, which is 'the legacy of physical artifacts and intangible attributes of a group or society that are inherited from past generations, maintained in the present and bestowed for the benefit of future generations' (Wikipedia 2010: 'cultural heritage'). Cultural resources are considered worthy of preservation for the future. Even if a culture still exists, cultural resources consist of 'series of segments', that include cultural context. Assume that are some photos capturing the moments. Every photo has different figures, but the series of photos explains what is going on. Each photo shows its context besides. That is called contextual resources. Without any contextual interpretation, any cultural resources cannot be understood clearly. So contextual resources must be in- 
cluded either naturally or synthetically.

Cultural resources are also known as information resources. Even if cultural resources act in the notion of contextual circumstances; the cultural products engaged in original placement are kept as information resources like text, vocal, images, motions and goods. Information resources as we knew are so ordinary that sometimes their existences are not realized. But the information resources are so effective when they are structured and organized. Library is a typical institution for organizing information resources. Libraries provide information service, which is organizing information on the basis of clienteles' needs. Information services include classification, cataloging, reference services, SDI, inter-library loan, delivery service, and even librarians' blogs. Eventually a library becomes an entity for information services; the librarian also synthetically roles as library itself for information services. So cultural resources are recognized as information resources, and cultural resources could be organized and served in terms of information services. What it means to organize cultural resources is to produce or reproduce their contextual resources.

As mentioned in previous paragraph, cultural resources consist of 'series of segments'. The segments could be information resources (such as text, images) and/or contextual contents for which any information expression could be represented. A cultural resource can be divided into several segments called single unit, which cannot be divided any further. Single units are not only from a cultural resource itself, but also imported from other cultural resources.
Therefore cultural resources can either be produced by creation, or reproduced by assembling other cultural resources. Every cultural resource is unique due to its creative processes and contexts.

Cultural resources are more complicated but synthetic (Green and Doershuk 1998). Each segment (single unit) has its own meaning and expression, and segments are grouped in phases, and form their meanings synthetically. When we enjoy paintings at an art museum, a group of paintings portray their meanings and contexts. And the exhibit flow tells another story. All these intended planning can be understood as a cultural resource or group of cultural resources. Sometimes an exhibition shows its intention through pamphlets or posters, called information resources.

Careful review of cultural resources arouses another idea. Are cultural resources interconnected? If they are, how are relationships expressed? As cultural resources internally consist of 'series of segments', which are also recognized as cultural resources, any independent-like cultural resources could be connected each other by any similarity like a place, time, historical affair and so on. If we can display these cultural resources on the map in terms of place, time and affair, almost every cultural resource could be connected entirely on three-dimensional map. The connections are shown as roads, highways on the map, and each cultural resource as village, town or metropolitan. By developing such a map, cultural and contextual resources are archived, preserved, exhibited and created. Cultural resources are broken down, and some segments are related to or implied 
into another cultural resources being connected by contextual relationship.

\section{Understanding and Utilization of Cultural Resources}

Cultural resources, to sum up in words, are characterized by contextual and synthetic properties. Cultural resources are structured by contextually forming cultural segments and synthetically connecting them. Then what makes cultural resources so valuable? Cultural resources are not only collected and preserved for a long time, but created and captured. Culture is to be cultural resources, the converse is equally true. Cultural resources could be considered as culture when they are understood and experienced by. It revolves eternally. Therefore cultural resources are produced and reproduced, if and only if they are not preserved but enjoyed. But preservation gives us chance for us to enjoy cultural resources which were produced long time age, in present time or in the future.

To enjoy cultural resources implies two conditions; exhibition (understanding), and integration (utilization). People recognize diverse cultures, understand each other and learn different culture through exhibition. When people accept and embody diverse cultures upon understanding them, it seems that cultural integration occurs by utilization of cultural resources. As results of utilization by cultural products, cultural contents and even change of thoughts are expressed. The more cultural resources are uti- lized, the bigger cultural industries become. To utilize cultural resources, the management thereof should be organized (served) and well structured.

Archiving (preserving and organizing) for cultural resources is the first step to utilize cultural resources. Archiving also includes the creation of new resources that explains the contextual background if necessary. Archiving has its own philosophy and methodologies, but if we understand why we have archived cultural heritages, it will be interpreted like that archiving of cultural resources is showing culture on the view point of its days. Cultural resources are preserved and organized with their contextual resources, which show how the cultural resources (cultural expressions) are dealt with during the same period of time.

Again it's necessary to mention what cultural resources are. Cultural resource can be thought as a 'resource' (which means value or utility) that is 'cultural' in character. The range that cultural resources cover so wide that it cannot be restricted (King 1998). Figure 1 shows how broad cultural resources are dealt with and how many disciplines concern them. Even the same phenomena could be interpreted differently with different cultural or research background. People produce cultural resources according to their own understanding of the culture. Furthermore vigorous interchange of socalled multi-faceted cultural resources is the challenge faced by cultural resource management.

Multi-faceted resources sometimes cause misconception and ambiguity. Due to various historical differences in organizing, documenting and managing cultural resources across cultural institutions, 


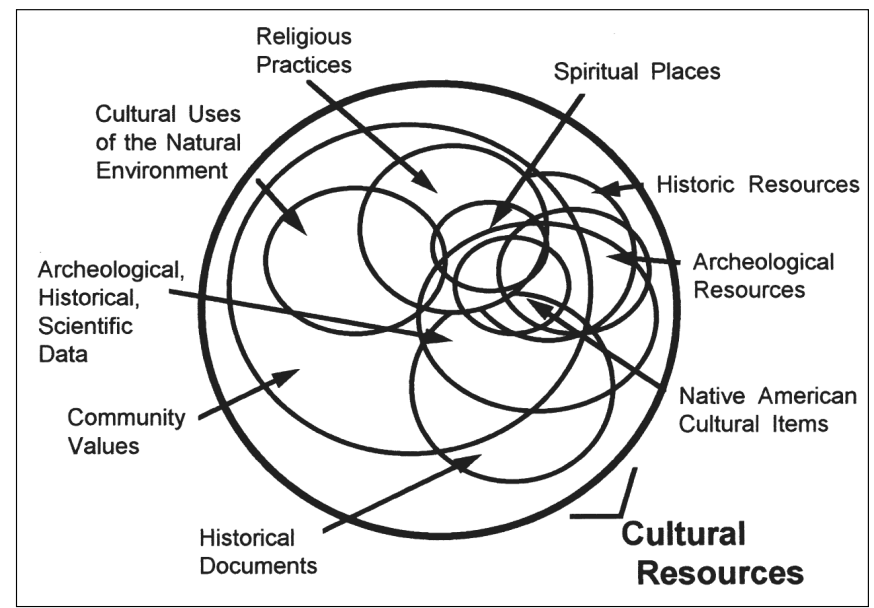

〈Figure 1〉 The universe of cultural resources (King 2000)

cross-domain resource discovery in the cultural heritage sector remains problematic. (Chaudhry and Jiun 2005). The upcoming new technologies can solve the problems the present time concerns. Cultural resources will be complicated, but transparent. Eventually cultural resources are going to be generated in digital forms and cultural resources management will be focused more on usability rather than preservation in digital archiving.

\section{Digital Archiving for Cultural Resources}

Cultural resources are meaningful when they are understood and enjoyed in meal or in malt. With the invasion of information and communication technologies in every aspects of human life, services of modern libraries and museums, digital archiving have become the new norm. It is seen to serve public interest by preserving cultural resources through ar- chives, museums and/or libraries. Each institution has its own characteristics, museum exhibits cultural heritages as they were, and library has the principle of usability. Regardless of different purposes of each institution, the ultimate goal is to pass down cultural legacies. Why do they try to pass down the legacy? The institutions try to preserve cultural heritages to show them later. What does it mean to show? People that preserve cultural remains wish to utilize the remains when they are exposed; but people who open them, hope them to be something in mind as memories (Lowenthal 1985).

One way of preserving cultural heritage is through recording relevant events. As with other newly invented technologies, making records were only allowed to a limited population due to its financial brdens. It is safe to assume that preserved records or cultural heritages, which would be the only means of preserving and passing down knowledge, were considered as treasures. Archaeologists had successfully utilized these resources to described the 
day-to-day lives of the culture and people. They also found the other values from cultural remains or records.

Archiving for cultural resources (records) requires keen sense of when to move records from one system to another, maintaining the records' authenticity, integrity, reliability and useability [usability] (ISO 15489, 2001). Records or cultural resources are evaluated only when archiving. If cultural heritages are kept safely, they could be valuable and meaningful.

Much of the discussion about preservation today is focused on 'digital archiving'. Two questions arise; how does digital archiving come about? And what are the differences between 'digital' and 'analog'? Before interpreting 'digital archiving', let think about 'digital libraries'. According to the review papers (Chowdhury and Chowdhury 1999; Chowdhury 2010), digital library is a space - a centre of intellectual activities - with content, available in different forms and formats in a distributed network environment, as well as tools and facilities for user-centric access, use, interactions, collaborations and sharing. They mentioned that there has been a paradigm shift by which most users have changed their habits to a great extent in the way they access and use information in the digital world.

Digital does not only mean change of media from analog format, but also changes in paradigm. To be more precise, it is rather a revolution, not merely a change. Change in social structure is also a result of digital revolution, as seen through inter-communication of knowledge and information via internet. Digital age affects almost everything, such as peoples' lives, industries, commerce, education, and even professionalism (Cain and Romanelli 2009). Now digital resources have become very popular in exchange and sharing of the resources. Individuals are capturing and storing an ever-increasing amount of digital resources about themselves or for themselves, including documents, digital images and audio and video recordings. People can now correspond via e-mail, create and maintain personal web pages, blogs, and electronic diaries.

In earlier stages of digital archiving, the main focus was on handling users and context information to build future digital preservation systems (Chowdhury 2010). Over the past decade digital archiving began to accept users who want seamless access to heterogeneous information resources regardless of its origin, creator, or format of the information that are managed. The information service institutions capture and organize the information resources created in the past, so that they can be accessed by community of the present; and also to make it easily accessible to the future generations.

Analog-oriented information process implies creation, publishing, dissemination and expansive reproduction. Authors (users), publishers and libraries are involved in the process. If analog resource is unique, then it should be stored and preserved carefully. Born-digital resources have different structural characteristics. Creation and utilization occur almost at the same time. Therefore the born-digital resources do not need to be disseminated as it can be accessed anywhere, anytime. Conclusively, digital archiving makes exhibition and exchange of re- 
sources/information possible without any restriction.

However the long-term digital archiving is a very challenging task, due to legality associated with intellectual property rights and policies, metadata structures, semantic support and other issues. Technical and socio-technical changes are driving archiving world to digital environment. Beyond the mere transformation, digital archiving brings new vision. Any digitally formatted cultural resources, even if these are personal, could be preserved easily making them mutually communicative, acessible, and enjoyable.

\section{Conclusion}

This paper starts with the question, what are culture and cultural resources? The meanings of cultural resources are mentioned historically and archaeologically. The culture dynamic is introduced and the cultural resources are interpreted as processes and practices along with which culture is produced and reproduced through the action of individual. Digital archiving concluds that the cultural resources are only meaningful when they are archived with their contexts and processes. Finally paper induces that cultural archives could be valuable, when they are preserved (synthetic), recognized (contextual) and enjoyed (exhibited, experienced or practically used).

Digital archiving for cultural resources is an 'important milestone' in the state of art of archiving and archives. Historically archiving and archives have pursued right succession of civilization and culture to mankind. The technologies adapted to archiving should evolved on the basis of principles; archiving therein informs and shows people their past and present.

\section{References}

Boyacigiller, N., M. Kleinberg, M. Phillips, and S. Sackmann. 1996. "Conceptualizing culture" In: B. Punnett and O. Shenkar (eds.), Handbook for International Research, Cambridge, MA: Blackwell, 157-208.

Cain, Jeff and Frank. Romanelli. 2009. "E-professionalism: anew paradigm for a digital age." Currents in Pharmacy Teaching and Learning, 1: $66-70$.
Chaudhry, Abdus Sattar and Jiun, Tan Pei. 2005. "Enhancing access to digital information resources on heritage: A case of development of a taxonomy at the Integrated Museum and Archives System in Singapore." Journal of Documentation, 61(6): 751-776.

Chowdhury, G. 2010. "From digital libraries to digital preservation research: the importance of users and context." Journal of Documentation, 
224 Journal of the Korean Society for Information Management, 27(2), 2010

66(2): 207-223.

Chowdhury, G. and S. Chowdhury. 1999. "Digital library research: major issues and trends." Journal of Documentation, 55(4): 409-448.

Green, William and John F. Doershuk. 1998. "Cultural Resource Management and American Archaeology." Cultural Journal of Archaeological Research, 6(2): 121-167.

Hofstede, G. 2003. Culture's Consequencies: Comparing Values, Behaviors, Institutions and Organizations Across Nations, 2nd rev. ed., Newbury Park, CA: Sage.

ISO. 2001. Information and Documentation - Records Management, Part 1: General [ISO 154891:2001(E)]: 19.

King, Thomas F. 2000. "What should be the "cultural resources' element of an EIA?” Environmental Impact Assessment Review, 20(1):5-30.

King Thomas F. 1998. "How the archeologists stole culture. A gap in American environmental impact assessment and how to fill it." Environ- mental Impact Assessment Review, 18(2): 117-34.

Lowenthal, David. 1985. The Past is a Foreign Country. New York: Cambridge University Press.

Martin, J. 2002. Organizational Culture: Mapping the Terrain, Thousand Oaks: Sage.

Mascarenhas, Andre Ofenhejm and Flavio Carvalho. de Vasconcelos. 2009. "What Does Captain Cook Have to Tell Us About Culture?" International Journal of Cross Cultural Management, 9(3): 323-338.

Schein, E. 2004. Organizational Culture and Leadership, 3rd ed., San Francisco, CA: Jossey-Bass.

Staber, U. 2006. "Social capital processes in cross-cultural management." International Journal of Cross Cultural Management, 6(2): 189-203.

Zimmerman, Diane Leenheer. 2006-2007. “Can our culture be saved? The future of digital archiving." Minnesota Law Review, 91(989): 989-1046. 